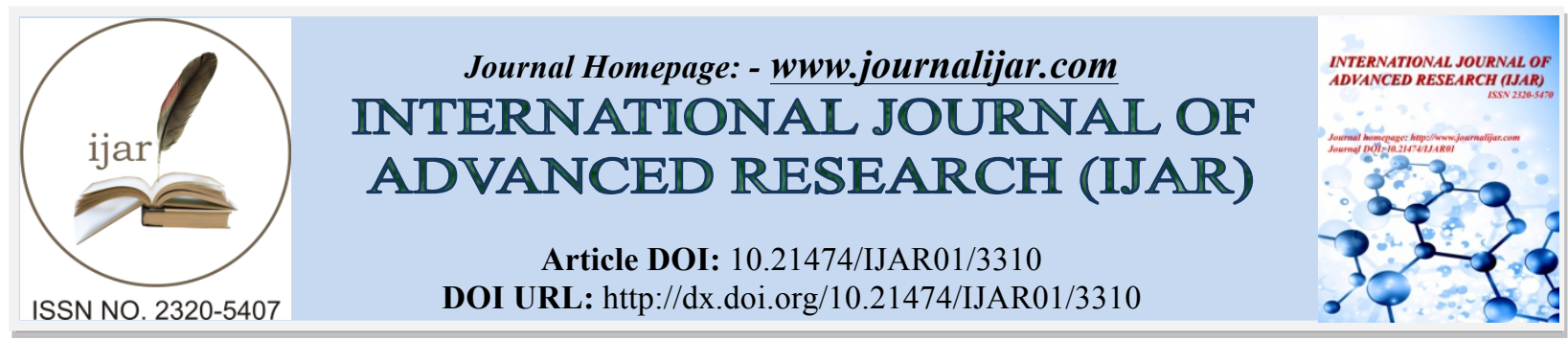

RESEARCH ARTICLE

\title{
STUDY ON ENVIRONMENTAL AND SOCIAL IMPACT OF SECOND PHASE SYRDARYA CONTROL AND NORTHERN ARAL SEA (SYNAS) PROJECT.
}

Aidana Oskenbayeva, Wenying $\mathrm{Xu}^{*}$, Ville Nyyssonen and Ramesh Kumar Neupane.

UN - Tongji Institute of Environment for Sustainable Development, Tongji university, Shanghai 200092, China.

\section{Manuscript Info}

Manuscript History

Received: 24 December 2016

Final Accepted: 16 January 2017

Published: February 2017

Key words:-

North Aral Sea, SYNAS Project, recovery, environmental impact, social impact

\section{Abstract}

The Aral Sea was once the world's fourth largest inland body of water, but has been forever altered by the USSR irrigation policies to reclaim the desert for cotton farming by rerouting the Amu Darya and Syr Darya rivers. The lake shrunk to a quarter of its original size in a few decades, creating an environmental and public health disaster. However, the completion of the Kok-Aral dam in 2005 (the first phase project) has yielded some positive results in recovery of the Northern Aral Sea recently. Local economies, long dependent on the water, were making a comeback. The second phase recovery project began in late 2012. The city of Aralsk has suffered most from a receding Aral Sea. The construction of a dam to raise the water to $46 \mathrm{~m}$ level in Saryshiganak bay will alleviate this problem. Environmental and social impacts of the second phase recovery project have been studied in this work, and the results have showed that further recovery of fish population, biodiversity, aquacultures, wildlife, fishery industry and local climate is expected after its completion. Implementation of this project will result in the increase of the total area of the Small Aral Sea, and as a result, increase the volume of water lost by evaporation from its surface to equalize the gain and loss parts of the water balance, stabilizing salinity. This will stop further freshening of the sea and associated adverse changes in its fauna.

Copy Right, IJAR, 2017,. All rights reserved.

\section{Introduction:-}

The intensive use of the Syrdarya water resources resulted, that the Aral Sea between 1960 and 201210 st $85 \%$ of its area and $92 \%$ of its volume.

The consequences of the crisis: as a result of directional falling levels of the Aral Sea since 1987, the pond was divided into two independent areas: the northern (Small) and southern (Big) Aral sea. More than $48000 \mathrm{~km}^{2}$ of the former sea bottom completely dried up (figure 1, table 1) (Micklin, 2003). Ecosystems of the Delta of the Syrdarya river transformed and degraded (Ogar, 2006).

Corresponding Author:- Wenying Xu.

Address:- UN - Tongji Institute of Environment for Sustainable Development, Tongji university, Shanghai 200092, China. 


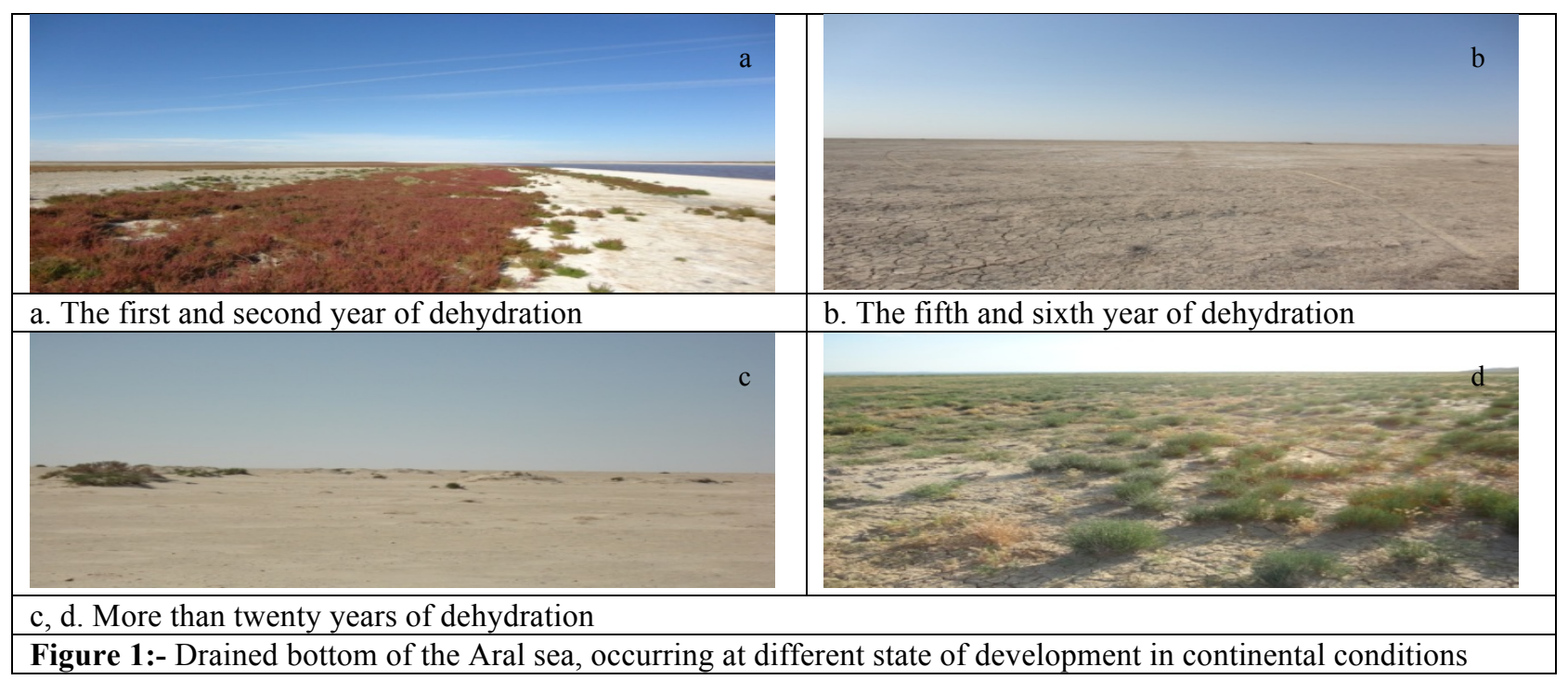

Table 1:- Shallowing and increasing salinity of the Aral Sea.

\begin{tabular}{|l|l|}
\hline The parameters of the Aral Sea \\
\hline for $1960:$ & for 2014 (North Aral Sea): \\
\hline Area- $68000 \mathrm{~km}^{2}$ & Area $-8300 \mathrm{~km}^{2}$ \\
\hline The volume- $1064 \mathrm{~km}^{3}$ & The Volume $-75 \mathrm{~km}^{3}$ \\
\hline Salinity $-10 \% 0$ & Salinity $-79 \%$ \\
\hline
\end{tabular}

Shrinking of lake systems. Monitoring observations with the use of remote sensing techniques and performance of instrumental observations allow to assess the real situation of the state of the deltaic lakes, including their water content: in 1967 the average water availability of lake systems were $339,2 \mathrm{~km}^{2}$, during extreme environmental situations in the Aral Sea area lake systems decreased from 306,2 $\mathrm{km}^{2}$ (1981) to $245,0 \mathrm{~km}^{2}$ (1989) (Budnikova, 2006; Dukravets, 1991).

Degradation of soil and soil cover. The main factor of soil cover degradation in the Kazakh part of the Aral Sea region and intensification of desertification processes is the regulation of the flow of the Syrdarya river. As a result, continuing the trend of reformation of water and salt regime in the delta natural complexes, increasing area of saline soils in irrigated areas, growing areas of new land within the former seafloor (Popov, 1984; Karajanov, 2004). The modern Delta of the Syr Darya river is characterized by heavy reclamation conditions, stagnant groundwater with a wide range of salinity (from 2 to $100 \mathrm{~g} / \mathrm{l}$ ), heavy mechanical composition of alluvial deposits (Kornienko, 1983). Periodic flooding of the wetland soils of present Delta contributes desalinization, but in a limited area (Demeeva, 2015). The main indicator of the tightening of environmental tensions in the Aral Sea region of Kazakhstan is a progressive growth of the saline soil areas within the Delta, and due to the desiccation of the former sea bottom (Karajanov, 2014) (figure 2). 


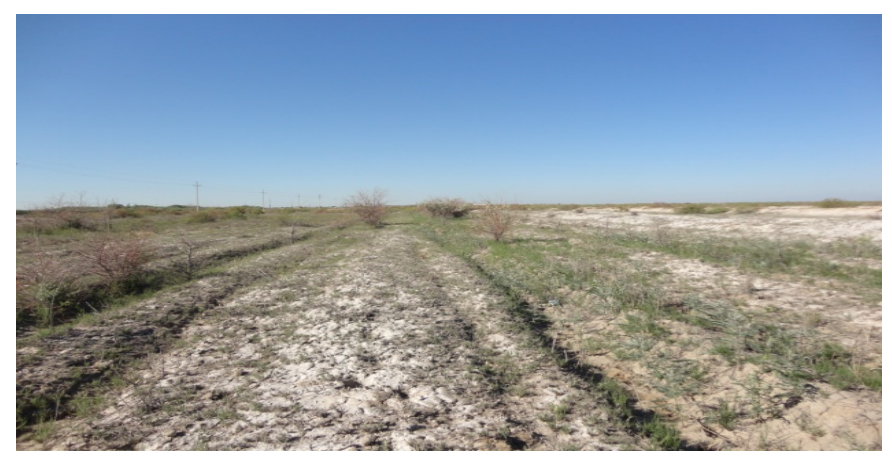

Figure 2:- Secondary salinization of irrigated lands (Kazakh part of Aral Sea)

Desertification. The process of desertification in the Aral Sea, as in any other arid region, flows stadial. At the initial stage (60s and 70s) signs of desertification were evident, but poorly manifested, and the process was still potentially reversible. In the second stage (after the 80s) degradation of the natural resource potential of the region has become critical and the process of desertification is irreversible (Borovskiy, 1981; Akiyanova 2006).

Changes in the bird population. In the early 60 s the Aral Sea was inhabited by over 300 species of birds (nesting 173 span - 123, accidental types of - 23), by the beginning of 2000s the avifauna of Kazakhstan the Aral Sea has lost about 70 species (Berezovsky, 1982; Kovalenko, 2005).

Changes in the fishery of the Aral Sea and reservoirs. The Aral Sea was once the third largest fishery water body of the USSR. In 50s and 60s 40-50 thousand tons was extracted, in 1980 - not more than 2,5 thousand tons. Since 1988, the sea has lost its fishery value (Karimov, 1997; Balymbetov 2005). The commercial fishing industry that developed during the first half of the twentieth century ended in the early 1980s as the indigenous species providing the basis for the fishery disappeared owing to rising salinity and loss of shallow spawning and feeding areas. Tensof-thousands were thrown out of work because of the loss of the fishery and associated activities and employment in these occupations today, although increasing because of the project to revitalize the Small (northern) Aral is still only a tiny fraction of what it was (Micklin, 2014).

In the frame of the inter-state co-operation of five Central Asian countries and "Program on the Aral Sea saving" in Kazakhstan a series of the measures, have been initiated, among which the «Syrdarya Control and the Northern Aral Sea» Project occupies a central focus. The phase 1 of the Project has already shown impressive results. The Kazakhstan Government is implementing the second phase project to restore the Small Aral Sea.

By the direct instructions of the President of Kazakhstan Nursultan Nazarbayev, one of the major projects initiated by the International Fund for Saving the Aral Sea (IFAS), is the project "The Syr Darya Control and North Aral Sea" (SYNAS-1) - the first phase (The project SYNAS-1, 2003-2010). The main idea of the President of the Republic of Kazakhstan N.Nazarbayev was to improve the environmental and socio-economic situation in the Northern part of the Aral Sea, where the main population of the Aral Sea region of Kazakhstan (Kipshakbayev, 2010). 
To maintain the integrity of the Northern Aral Sea, the $13 \mathrm{~km}$ Kokaral Dike was constructed to separate the Northern Aral Sea from the South Aral Sea. Completion was in August 2005.

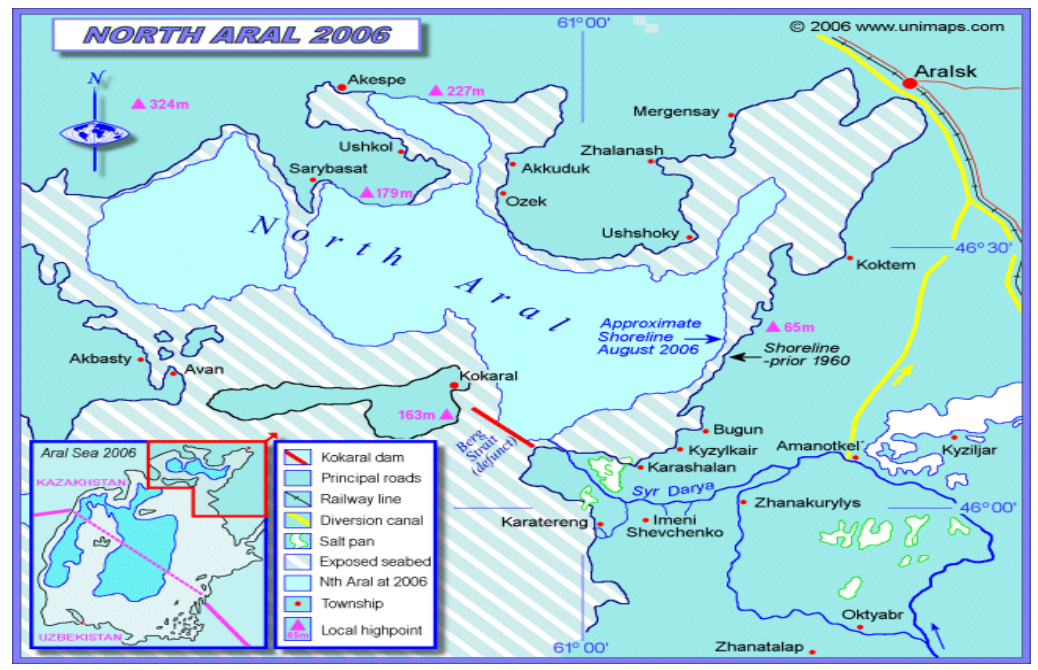

Figure 3:- The location of the Kokaral dam (Phase 1)

There have been several attempts to block the Small Aral Sea by a dam, so the water could not go away, but they were unsuccessful - the stormy waves of the lake destroyed the dam. The situation changed after the construction of Kokaral dike. In two years, the Small Aral Sea is almost completely filled with water, the sea got closer to Aralsk city, climate has changed dramatically for the better.

Table 2:- Changes of indicators of the North Aral Sea after the construction of Kokaral dike (Aladin, 2011)

\begin{tabular}{|l|l|l|l|l|l|l|l|l|l|}
\hline Indicators & 1970 & 1988 & 2003 & 2004 & 2007 & 2008 & 2009 & 2010 & 2011 \\
\hline The water level, m & 53 & 40 & 30 & & 42 & 42 & 42 & 42 & 42 \\
\hline The volume, $\mathrm{km}^{3}$ & 82 & & & 15,6 & & & & 27,1 & \\
\hline $\begin{array}{l}\text { The surface area, } \\
\text { thousand } \mathrm{km}^{2}\end{array}$ & 6,118 & & 2,55 & & & 3,3 & & & \\
\hline Salinity, \%o & $8-13$ & 30 & & 23 & $11-14$ & & 12 & 17 & 9 \\
\hline
\end{tabular}

\section{Project Outcomes:-}

The Phase 1 Project has already shown impressive results:

$>$ Eliminated the threat of extinction of the Northern part of the Aral sea;

$>$ Raised the water level of the Small sea from 39.90 m BS to 42 m BS;

$>$ Increased area of sea from 2414 to $3262 \mathrm{~km}^{2}$;

$>$ Increased the volume of water in the Small sea from 15.6 to $27.1 \mathrm{~km}^{3}$;

$>$ The Sea became closer to the city of Aralsk from 75 to $17 \mathrm{~km}$;

$>$ Reduced the level of mineralization of the Northern Aral sea from 23 to $17 \mathrm{~g} / 1$;

$>$ Restored several lake basins in the area of 20-30 hectare, which gave the opportunity to further develop the fisheries activities;

Created favorable conditions for reproduction of commercial and valuable species of fish (restored 13 species previously extinct, the volume of the catch increased from 0.4 to 5.0 thousand tons) (Water Feature Stories, 2008). 
In 2005, during the visit of objects of SYNAS-1 by President N. Nazarbayev was given high evaluation and significance of technical installations of project, and was proposed to continue work on the stabilization and improvement of ecological and socio-economic situations in the Aral sea. The "The Syr Darya Control and North Aral Sea" (SYNAS-2) project is to continue the SYNAS 1 successful development of the Kazakh Syrdarya Basin in terms of improving living conditions for its inhabitants, improve safety, and to improve environmental conditions (The project «SYNAS-2»).

The proposed SYNAS-2 would be designed to improve further the environmental and economic conditions along the Syr Darya and the NAS. It would build on the work done under SYNAS-1. This would be achieved by focusing more on integrated water resources management in the basin, which would require a number of structural interventions and strengthening the institutional and management capacity for integrated water resources management in the basin.

The aim of the SYNAS-2 project is to increase the bandwidth of the lower part of Syr Darya, sustainable water supply and rehabilitation of the Delta lakes, as well as strengthening the capacity of the government in the field of river basin management that should be implemented in two stages. The first phase of the project, consists of 6 components, component names and places where they will be implemented activities are listed in figure 4 .

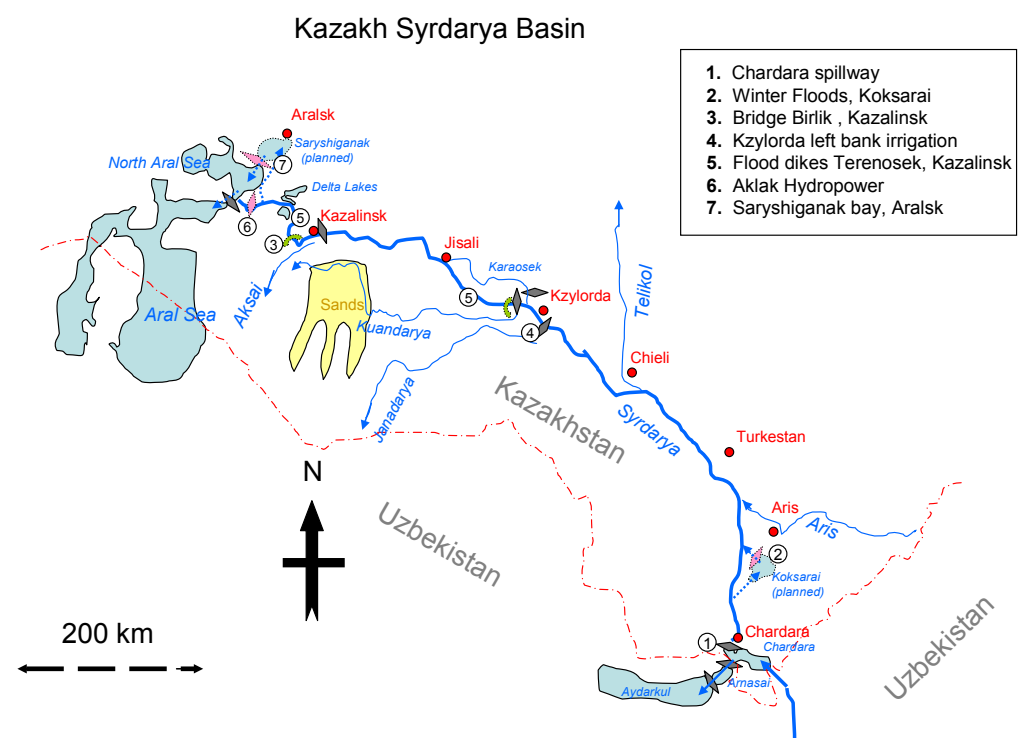

Figure 4:- Map-scheme of location of the SYNAS 2

The Feasibility Study «Complex of structures in Saryshiganak bay» is part of the second stage of the "Northern Aral Sea" development. It foresees the flooding of the significant part of Saryshiganak bay and brings water back to the city of Aralsk, considerably improving the microclimate and ecological situation in the coastal area and in Aralsk. Creation of navigable access to the Northern Aral Sea allows to use partially the existing harbor, shipyard and fish processing industries, to organize commercial fish catch in the whole Northern Aral Sea, to create new working places, to improve social-economic level of the population. 


\section{Site location:-}

Saryshiginak Bay is situated at the northern extremity of the Aral Sea between N 46 and 47 degrees and E 61 and 61 degrees 30. The dam will be constructed near the northern limit of the existing North Aral Sea, where the east and west banks are only separated by a short distance. The Bay will be supplied with water by means of a canal fed by an intake on the right bank of the Syrdarya river some $20 \mathrm{~km}$ upstream Aklak weir.

Table 3:- Description of the principal dimensions of new dike in Saryshiganak Bay

\begin{tabular}{|c|c|}
\hline \multicolumn{2}{|c|}{ Principal dimensions } \\
\hline length & $10.7 \mathrm{~km} ;$ \\
\hline maximum height & 8 to $9 \mathrm{~m}$ (to be confirmed by site survey); \\
\hline crest level & $48.4 \mathrm{~m} ;$ \\
\hline crest width & $10 \mathrm{~m} ;$ \\
\hline downstream slope & $1 \mathrm{v}: 2 \mathrm{~h}($ with a 4 m wide berm at level $43.5 \mathrm{~m}$ ); \\
\hline fill volume & $620,000 \mathrm{~m}^{3}$. \\
\hline
\end{tabular}

Objective of this paper: to study the social and environmental impacts of the second phase "Syrdarya Control and Northern Aral Sea (SYNAS)" Project designed to elevate the water level in Saryshiginak Bay by filling the reservoir formed after construction of a new dam across the entrance to the Bay with the diverted water from Syrdarya River. This study will summarize some of the research findings made by scientists from different disciplines after completion of the Feasibility Study "Complex of Structures in Saryshiganak bay".

\section{Research Methodology:-}

In the first step the appraisal of the proposed projects effects on the targeted communities was carried out as appraisal of various stakeholder categories opinions and perceptions as regards the projects socio-ecological effects.

This type of participatory research was selected because it allows to:

1. forecast public support or opposition to decisions that will have been made on the projects,

2. refine public education strategy in the cases where misunderstanding and distortion of information as regards the proposed projects are detected, and

3. refine the projects at the feasibility study and implementation stages to better meet the affected stakeholders groups needs and reduce costs and potential temporary or permanent negative impact.

The analysis was carried out as a series of interviews with pre-determined categories of stakeholders. People were interviewed on the projects that

1. they have comprehensive technical knowledge of,

2. would affect their life and work conditions in an immediate way, or

3. are recurring discussion points at the political and social agenda locally and nationally.

A distinctive feature of this analysis was that the surveyed stakeholders' collective or individual opinions were not ascribed weights that would have reflected respondents' technical expertise, status in the hierarchy of authority either official or unofficial, income, education, or other socio-economic characteristics. All the obtained information constituted an array of arguments that were supportive or critical of every individual project from a socio-economic perspective. Only in the final analysis matrix weights were assigned to categories of socio-economic indicators. 


\section{Socio-Economic and Ecological Analysis:-}

\section{SYNAS-II Project Social-Economic Appraisal Matrix:-}

One hundred six respondents were surveyed. All opinions expressed by the interviewed stakeholders were classified as either

- "Red", i.e., arguments against a project in relation to a particular indicator,

- "Yellow", i.e. arguments that delineate conditions under which a project may be supported, otherwise it should be rejected, or

- "Green", i.e. arguments in support of a project.

Subsequently a number of distinct "green", "yellow" and "red" arguments were counted per each indicator. Further weights of "green", "yellow" and "red" arguments were calculated as a ratio of a number of arguments in each category to a total number of all arguments per individual indicator.

Obtained numbers for the safety indicator were multiplied by 2 , while numbers for the political gain indicator were divided by 2 . Numbers on the remaining indicators were not weighted. Total project rank was calculated as a sum of the all indicator numbers.

The projects that received only positive scores could be considered as most socially urgent and relevant. No controversy over their goals or proposed implementation schemes was elicited.

Goals of the projects that received a mix of positive and negative scores were not highly contested. However disagreement as regards their implementation and intended and unintended consequences were elicited. Further consultations, negotiations and public awareness activities may be needed.

Projects that received equal positive and negative or predominantly negative scores need revision, awareness raising campaign, lobbying, and new in-depth expert discussion.

The following opinions were collected and categorized according to five themes. The colours green, yellow and red indicate respectively recorded support, ambivalent opinion or opposition. 
Table 4:- Socio-economic appraisal matrix

\begin{tabular}{|c|c|c|c|c|c|}
\hline $\begin{array}{l}\text { Indicator } \\
\text { Project }\end{array}$ & $\begin{array}{l}\text { People, } \\
\text { livelihoods and } \\
\text { agricultural } \\
\text { lands safety }\end{array}$ & $\begin{array}{l}\text { Enhancement of } \\
\text { income } \\
\text { generation } \\
\text { opportunities }\end{array}$ & $\begin{array}{l}\text { Ecological } \\
\text { rehabilitation, } \\
\text { creation, } \\
\text { enhancement of } \\
\text { human health }\end{array}$ & $\begin{array}{ll}\text { Revival of } \\
\text { traditional } \\
\text { habitats, } \\
\text { emotional and } \\
\text { moral } \\
\text { renaissance }\end{array}$ & $\begin{array}{l}\text { Impact on } \\
\text { Kazakhstan's } \\
\text { political and } \\
\text { economic } \\
\text { development } \\
\text { prospects and its } \\
\text { role in Central } \\
\text { Asia }\end{array}$ \\
\hline $\begin{array}{l}\text { The complex of } \\
\text { dam structures in } \\
\text { the Saryshiganak } \\
\text { bay, provision of } \\
\text { water to Aralsk } \\
\text { harbour }\end{array}$ & $\begin{array}{l}0 \\
1(106 / 106) \\
0 \\
+1 \times 2=2\end{array}$ & $\begin{array}{l}0.8(85 / 106) \\
0 \\
0.2(21 / 106) \\
+1\end{array}$ & $\begin{array}{l}0.66(70 / 106) \\
0 \\
0.33(36 / 106) \\
+1\end{array}$ & $\begin{array}{l}0.66(70 / 106) \\
0.33(36 / 106) \\
0 \\
+1\end{array}$ & $\begin{array}{l}1(106 / 106) \\
0 \\
0 \\
+1 \times 0.5=0.5\end{array}$ \\
\hline
\end{tabular}

\section{Comment:-}

$2+1+1+1+0.5=+5.5$

Overall, this project has an incontestable moral and political value both at the local and at the national and international level. Material gains for the affected population may also be significant.

\section{Results and Discussion.}

\section{Social impact of the project:-}

Filling up the Northern Aral Sea has become an integral part of the Aralsk district life. After the SYNAS-I people have believed that the once impossible task of the revival of the NAS may turn into real and feasible projects. Therefore no one opposed this idea and the line that the Aral Sea needs to be revived at all costs has become a guiding principle.

Major direct beneficiaries of this project will be people in the Aralsk District. First of all the environment will be affected in a positive way. Climate will get milder due to the replenishment of the Saryshiganak bay and this will positively impact people's health. There will be more rains and less dust storms. Environmental effect of the construction of the Saryshiganak bay dam, however, was perceived as arguable for the Kazalinsk district. The Small Sea will be replenishing while the Large Sea will further desiccate, while salt and sand winds blow from the dry bottom of the Large Sea. It is these winds that cause respiratory system diseases.

Material gains would be substantial. Turning Aralsk into a port would attract investments into the city. Second, replenishment of the NAS will lead to the increase in fish catch. This will stimulate fish factories revival in Aralsk. Processed fish will go up in price compared to raw fish.

The boat fleet will be revived to transport fish to Aralsk. Sea transport is a cheaper alternative to the transport by land. Jobs in the fish processing, fleet and fleet maintenance sectors will be created. A canal that would start before the river delta and become a shortcut between Syrdarya and the presently desiccated Saryshiganak bay has an added value as it presents the surrounding villages with a supplementary water reservoir as a pond for cattle and water 
supply for melon cultivation. However those who live around the river mouth may not enjoy this revival to the same extent as the population of Aralsk itself and the surrounding villages.

Most benefits of the project in the opinion of the interviewed stakeholders concerned renaissance of the entire Aralsk district. Return of the sea and the subsequent improvement of the employment situation and investment climate would lighten the atmosphere in the city and empower people. Those who have never left the area regardless of the government's invitation to resettle would be morally satisfied. Those who have left Aralsk will be happy to return once jobs and other income generation opportunities present themselves should the replenishment of the NAS progress. Replenishment of the Aral Sea would reduce stress over the loss of the traditional habitat, social and economic decay and struggle for survival that have become a background for those who used to live off the sea.

Aral Sea is at the core of identity of people who've been living there for generations. Return of the sea would strengthen distinct collective identity and foster patriotism. Fame of Aral fishermen and fish factories will be restored. Professional cadre is still there, ready to work and train new specialists. Political gains are clear. Replenishment of the NAS is a test for the ability of the President to keep his promises.

Although no serious opposition to this project was expressed, there were voices that called for a more careful and less euphoric approach to this project. First, the dam construction is a high risk enterprise. Should the dam be washed away or destroyed there would be a catastrophic flood. Therefore careful calculations and perfect implementation are of key importance. Second, selection of the start of the channel into the Saryshiganak bay is vital because there is a danger that water from the lakes such as Tushibas would spill into this channel. An alternative is to reconstruct old natural channels that once connected the lakes with the sea.

As regards climate change sceptics say that the area of the Saryshiganak bay is not large enough to affect climate change.

Replenishment of the Saryshiganak bay would not make any difference for Kazalinsk rayon.

Overall, this project has an incontestable moral and political value both at the local and at the national and international level. Material gains for the affected population may also be significant.

\section{Ecological Section:-}

The project encompasses a cutoff dike of maximal $10.7 \mathrm{~km}$ length at Saryshiganak Bay with a maximum height of 9 $\mathrm{m}$, an adduction canal of about $46 \mathrm{~km}$ length with a discharge capacity of $50 \mathrm{~m}^{3} / \mathrm{s}$ which would take off from the Tushibas Lake near Bugun village. Various water levels in the bay have been investigated between $45 \mathrm{~m}$ and $50 \mathrm{~m}$. A complete restitution of the ancient Aral Sea water level in the bay of about $50 \mathrm{~m}$ will not be possible, as not enough gradient will be available from Syrdarya for the necessary transport length. While lower water level covers only part of the lake and the highest water level would almost reach Aralsk harbour, the costs for increasing the dam height becomes disproportional high, and vice versa, low water levels would increase disproportionally the access canal length and depth. A feasible compromise seems to be $46 \mathrm{~m}$ operational water level. The envisaged water level will require dredging to realize a navigable access to Aralsk harbour for ships up to a draft of $2 \mathrm{~m}$. 


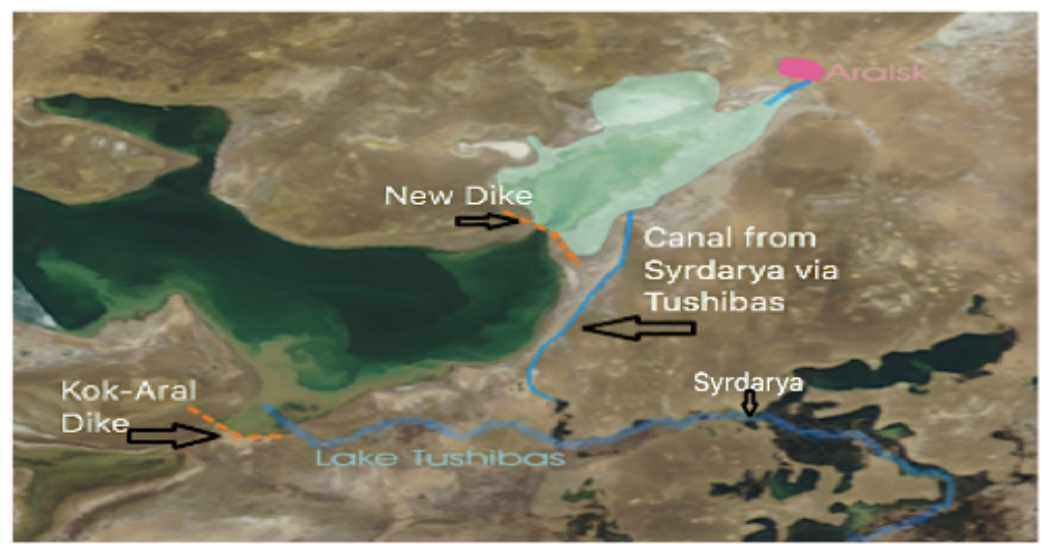

Figure 5:- Saryshiganak project area with dam (orange), supply canal and access canal to Aralskharbour (blue) and flooded area (transparent) Remark: The flooded area was taken from an bathymetric map which was not entirely exact as the satellite image shows (Phase 2)

Inflow to Saryshiganak lake will be by diverting flows from the Syrdarya, through Tushibas lake and via a $46 \mathrm{~km}$ canal to a discharge point at the east side of the lake. The project would bring the gulf back to the town of Aralsk the former main port and transshipment point at the northern end of the Aral Sea.

The reservoir created would have near fresh water salinities of $2-3 \mathrm{~g} / \mathrm{l}$. Locks would be installed at the dam allowing passage of fishing and cargo boats from the main part of the Small Aral to the gulf and vice versa. This would allow fishing vessels direct access to unload their catch at the newly rebuilt and quite modern fish processing plant in Aralsk.

As an alternative the increasing of the new Kokaral dike by $4 \mathrm{~m}$ to achieve a raise of the water level in the entire NAS up to $46 \mathrm{~m}$ was considered during the pre-feasibility study. This option would require significantly more water (more than the annual $3 \mathrm{~km}^{3}$ ) which is currently not sufficiently available from the Syrdarya River which would cause long times for filling the entire NAS. However, a further increase in the level of the NAS to $46 \mathrm{~m}$ would require about USD 92 million investments in dike construction and additional considerable investments in upgrading of irrigation infrastructure along the Syrdarya River in order to save more water to reach the NAS.

\section{Environmental Impacts:-}

\section{(a) Impacts on the hydrology of the river system:-}

The water supply for the Saryshiganak Bay will be realized by withdrawal from the Syrdarya River via Lake Tushibas and a canal of $45 \mathrm{~km}$ length and $50 \mathrm{~m}^{3} / \mathrm{s}$ discharge capacity from the northern edge of Lake Tushibas. The annual withdrawal for covering the losses due to evaporation, losses through the sluice and infiltration from the canal will be $0.556 \mathrm{~km}^{3}$. The impact on the Syrdarya River system, by reduced runoff and - depending on the timing of withdrawal - changing of the flood dynamics concerns the river course downstream from the canal supplying the Lake Tushibas, in effect the last few kilometers. The water supply will be ensured by the Aklak weir (upstream water level at summer $53.5 \mathrm{~m}$ asl. During winter, the same operational level needs to be assured for feeding Saryshiganak bay and assuring sufficient head for hydropower production. 


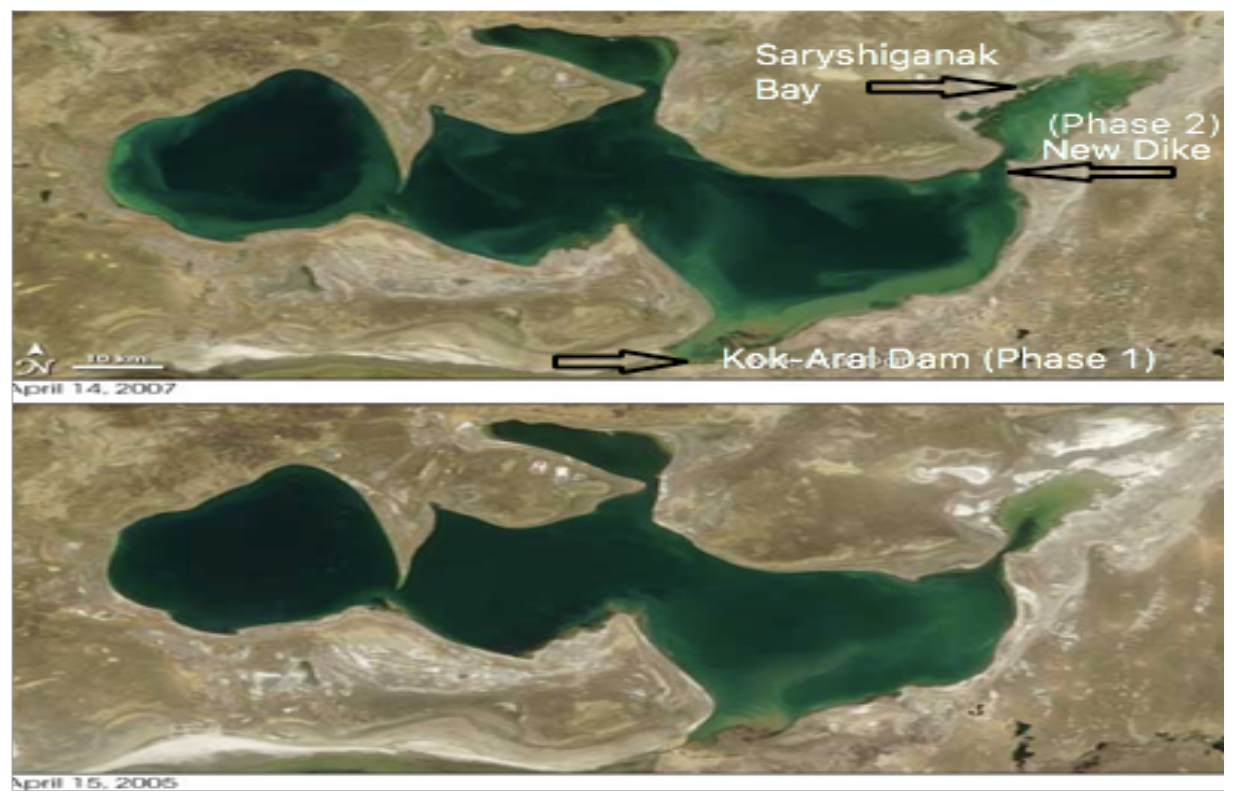

Figure 6:- Pictures of the North Aral Sea before (below) and after (top) construction of the Kokaral dam (April 2005 and April 2007 comparisons)

Images showing the recent flooding of already about $50 \%$ of the Saryshiganak Bay area to be rehabilitated under the project. Consequently, as project impact only evaporation losses from additional water surface should be calculated.

The impact on surface waters is not very significant for the Syrdarya River and the NAS. On the Lake Tushibas the impact concerns the maintenance of a maximum water level during the times of water supply to the bay. In what extent this will change the current hydrological conditions needs to be studied. It is positive for the Saryshiganak Bay, which will be revived as a water body of $593.6 \mathrm{~km}^{2}$ with a volume of $1.76 \mathrm{~km}^{3}$. The construction of the KokAral dike already caused the reestablishment of a water surface area of roughly estimated one half of the surface of the Saryshiganak Bay. Due to the withdrawal the annual inflow into the NAS and consequently into the Large Aral Sea (LAS) will be reduced by $0.23 \mathrm{~km}^{3}$, i.e. the evaporation losses from the additional water surface of the bay. The water released through the ship lock and infiltration water from the supply canal flow into the NAS. Against the backdrop of the highly negative water balance of the LAS of several $\mathrm{km}^{3}$ per year, the reallocation of this water amount to a part of the Aral Sea - where its positive impact is considerable higher and sustainable - is acceptable.

In the vicinity of the re-established water body of the Saryshiganak Bay the ground water table will increase but remain below the level of the 1960s. Infiltration losses from the canal can cause local ground water table increase in the shore areas of the NAS.

\section{Impacts on water quality:-}

The project will have no impact on river water quality. During the construction period water pollution can occur from used machinery. This pollution has to be minimized by observing the required standards for machinery and transportation means. The pollution of the Syrdarya River water will be the determining factor for the water quality 
in the Saryshiganak Bay. In contrast to the situation prior to the drying out when the Saryshiganak Bay was without freshwater inflow and thus belonged to the comparably saline areas it will now become a fresh water lake.

The flooding of the Saryshiganak Bay and the spillage of water through the sluice into the NAS from the north will improve the mixing of the NAS water of high salt content with fresh water from the Syrdarya. On the other hand, salt accumulation and toxic substances at the dry seabed in the bay will become dissolved and moved into the NAS. The proximity of the city of Aralsk to the re-established bay, the operation of the rehabilitated harbour and an increase of ship traffic can cause pollution of the Aral Sea by domestic and industrial sewage.

Desalinization of the Saryshiganak bay water will be achieved fairly rapidly. It should be mentioned, that during the drying out process, no residual salt pans accumulated in the bay, but that the waters retired towards the main body of the NAS, without leaving excessive salt incrustations. The relation between a high volume $\left(1.76 \mathrm{~km}^{3}\right)$ of fresh water (max $1.8 \mathrm{~g} / 1 \mathrm{salt}$ ) brought to the bay and the comparatively small amount of salts accumulated in the Solonchak layers (max $5 \%$ within a depth of $0.5 \mathrm{~m}$ on a surface of $594 \mathrm{~km}^{2}$ ) on the dried out lake bottom will create and maintain a lake, whose salinity will be about $10 \mathrm{~g} / \mathrm{l}$, a concentration which is lower than in the NAS and which will gradually decrease with the yearly water exchange. This will impact positively on the distribution of commercially higher priced sweet water fish species.

At present the high salinity of the ground water in most wells of the NAS area limits its utilization as drinking water. The unknown patterns of ground water salinity and their relation to the Aral Sea level make a prediction of impacts on well drinking water difficult. A deterioration of ground water quantity and quality in the context of the drying of the sea is reported from the villages in the proximity of the former shoreline. Thus the rehabilitation of the water body will most likely have a positive impact.

\section{Impacts on atmospheric air :-}

From the rehabilitation of the water body a positive impact on the local climate in the vicinity is expected. This concerns higher air humidity and a less continental temperature regime. The dry Aral seabed, in particular in the Saryshiganak bay is considered being the major denudation source of frequent salt dust and sand storms in Aralsk and the region. The flooding of a considerable area, including the most critical substrates with high salt content should lead to a mitigation of these problems.

\section{Impact on soils:-}

The impact on soils includes flooding of dry seabed, which is considered positive. The areas of former seabed, which will remain open are mostly sand substrates which are well covered by vegetation. Further impacts on soils are the effects of construction of canal, dam and access road, including opening of borrow pits. The source of material for dam construction has been identified directly to the east of the damsite. Impacts should be minimized by restricting the area and mitigated by allowing a re-cultivation or a protected self-regeneration of borrows pits. The utilization of the excavated material from the canal for construction of the dam should be considered. The canal would be along the former seashore in largely sandy substrates. This can cause problems with infiltration losses. 


\section{Impacts on biodiversity:-}

The project will have the major effect of restoring in a large extent of the former landscape before drying out of the bay. Significant areas of dry seabed will however remain as the water level will be still $4 \mathrm{~m}$ below the level of the 1960s. The impact of the construction of the dam and the supply canal will be local by character. When constructing the canal the material could likely be used for dam construction and thus the creation of dams along the canal be avoided.

The restoration of the Saryshiganak Bay will cause the flooding of vegetation established since the drying out. This vegetation consists of typical representatives of the psammophilous desert vegetation and in the lower parts of salt tolerating plants. In the area of canal and road construction and at the borrow pits for the dam construction the natural vegetation will locally be destroyed. The affected areas are not significant (few hundred hectares). The restoration of the lake ecosystem in the bay is considered positive impact by far outweighing the loss of secondary desert vegetation on the dry seabed and comparable small sections of desert vegetation outside. Among the fish, economically more attractive fresh water species will prevail. However it should be recognized that the flooding via a canal will cause conditions, which are in terms of water chemistry, significantly different from the former brackish water and the new developing ecosystems will thus differ from the previous ones.

During the detailed design studies, analysis should be done on how to populate the Saryshiganak bay fastest with fish. The present owners of fishery rights in Tushibas lake might prevent the most obvious path, directly by canal inflow from the fingerlings released from Tastak and Koszhar hatcheries on Syrdarya. For fish population and fish migration it would be important to have at least a temporary passage allowed. This can be achieved for instance by electric fish repellent structures at the Tushibas canal intake. Although not as effectively, fish could also travel via the locks and to a lesser extent via the bottom outlet in and out of the Saryshiganak bay. Initial fish population could also be realized by transport of fingerling by tanker trucks to the lake sites.

The Saryshiganak Bay is a part of the proposed Important Bird Area "Small Aral Sea". The most important species are water related birds as e.g. White and Dalmatian pelican and ferruginous duck. Those species may profit from the increase of the lake. However the raising of the water level can as well adversely affect waterfowl species because of changes of the water chemistry impacting on the fodder basis and distribution as well as extent of shallow areas with loamy substrates. The water body of the Saryshiganak Bay will in most areas reach the sites with steeper slopes and sand soils with higher vegetation. This will significantly reduce shallow water and salt marsh areas. Species breeding in areas with shallow waters or on flat places with sparse vegetation as diverse waders, among them the endangered steppe pratincole, white-tailed plover, Kentish plover or lark species, including the rare Asian short toed lark may lose breeding sites. The loss of shallow water areas will likely as well affect numerous migratory birds resting there. The construction of the Berg Strait dike and the raising level of the NAS already caused the loss of extensive feeding and resting areas in the region of the Syrdarya Estuary. The impact of the raising NAS level has been documented in the final monitoring report of Scott Wilson (2007). Unfortunately the Saryshiganak Bay was not included in the monitoring sites of Scott Wilson and the data basis on birds in this specific area is scarce. 
The project has a positive impact on the ichthyofauna by increasing the fish habitats and reducing the salinity in sections of the NAS as described above. At the moment it cannot be predicted if the fish fauna of the area would be rehabilitated by immigration via the supply canal or if a fish ladder at the dam should be considered. The fish ladder could be combined with a spillway for release of fresh water into the NAS.

Table 5:- Future fish catch in the NAS and Saryshiganak bay

\begin{tabular}{|c|c|c|c|c|c|c|c|c|c|c|c|c|c|}
\hline \multirow{3}{*}{ Location } & \multirow{3}{*}{$\begin{array}{l}\text { Surface } \\
\mathrm{km}^{2}\end{array}$} & \multicolumn{6}{|c|}{ Quantity of fish caught ( $t)$} & \multicolumn{6}{|c|}{ Gross margin (1000US\$) } \\
\hline & & \multicolumn{6}{|c|}{ Years } & \multicolumn{6}{|c|}{ Years } \\
\hline & & 1 & 2 & 3 & 4 & 5 & 6 & 1 & 2 & 3 & 4 & 5 & 6 \\
\hline & & & & & & & & & & & & & \\
\hline $\begin{array}{l}\text { Nothern Aral Sea (SYNAS report 1999), } \\
\text { without project }\end{array}$ & 3243 & 917 & 1113 & 1310 & 1507 & 1703 & 1900 & 305.83 & 371.19 & 436.90 & 502.60 & 567.96 & 633.66 \\
\hline NAS fish catch forecast corrected & 3164 & 1910.00 & 3633.00 & 5356.00 & 7079.00 & 8802.00 & 10525.00 & 637.00 & 1211.63 & 1786.27 & 2360.90 & 2935.54 & 3510.17 \\
\hline Saryshiganak Bay & 594 & 350.00 & 1930.00 & 3510.00 & 5090.00 & 6670.00 & 8250.00 & 139.54 & 769.47 & 1399.39 & 2029.32 & 2659.25 & 3289.17 \\
\hline Total & 3758 & 2260.00 & 5563.00 & 8866.00 & 12169.00 & 15472.00 & 18775.00 & 776.54 & 1981.10 & 3185.66 & 4390.22 & 5594.78 & 6799.34 \\
\hline
\end{tabular}

Gross margin per ton of fish US \$/t

NAS: $\quad 333.51$

Saryshiganak: $\quad 398.69$

Scientists estimates that creation of a large fresh water reservoir in the bay will create additional fishing grounds and the accelerated desalinization will increase the productivity of valuable fish species of low salt tolerance in the NAS. This will outweigh the further reduction of flounder catches caused by the reduced salinity.

The benefits of construction are calculated based on the expected growth of fish catch in the Sea and Saryshiganak bay as well as on the expected improvement of population health at the territories adjacent to the Sea.

$>$ Growth of fish catches in Saryshiganak bay will be based on a growth from 350 tons to 8250 tons per year within six years, assuming a gross margin per tonne of qualitatively more valuable fish of US \$399.

$>$ Growth in Northern Aral Sea will be based on a growth from 1910 tons to 10525 tons within six years, assuming a gross margin per tonne of fish of US \$ 333 .

Despite of some predictable negative impacts on the current biodiversity at the dry seabed the overall impact of the restoration of parts of the former sea area is considered overly positive. The development of new biocenoses will start immediately with the restoration of the water body. The impact on biodiversity needs to be further studied in the frame of the detailed design study.

\section{Impacts on human environment:-}

The expected reduction of salt dust in the air and potential improvement of the quality of ground water used as drinking water in villages close to the sea will have a considerable positive impact on human health. The restoration of a water body in the bay dry for decades will have a positive mental effect on the local population. 


\section{Worst case scenario:-}

The worst case scenario would be the failure of the dam similarly to the previous Kok-Aral dike. This has to be prevented by an appropriate construction design and execution. The volumes to be released from Saryshiganak bay would be absorbed by the NAS and the existing NAS dam spillway. In the worst case, in which the water level of the NAS would rise to an unacceptable level, the earth fuse plug in the NAS dike will fail and release the water without further damage to human lives or property to the Main Aral Sea. The upstream slope must be protect from erosion by wave attack. With a maximum fetch of $40 \mathrm{~km}$ and a design sustained wind speed of $30 \mathrm{~m} / \mathrm{s}$ (equivalent to the 1 in 1000 year event), it is estimated hat the average height of the resultant waves could be $1 \mathrm{~m}$ and the 1 in 100 wave would be $2.1 \mathrm{~m}$. To sustain the force of such waves the mean stone diameter should be $0.7 \mathrm{~m}$. Further it is crucial for the stone protection to be bedded on coarse highly permeable gravel of a suitable grading overlying a sand filter material. The downstream slope will be protected, where it is vulnerable to wave attack from the NAS, by the coarse material of the downstream cofferdam. A spillway of $45 \mathrm{~m}^{3} / \mathrm{s}$ capacity is required to ensure the embankment cannot be overtopped.

\section{Conclusion about the environmental impact:-}

The project has positive impacts in terms of hydrology, air, landscapes and human environment. The evaluation of impacts on biodiversity requires further assessment. So far positive as well as negative aspects are expected, with the positive aspects likely dominating. No clearly negative environmental impacts have been identified.

\section{General Conclusion:-}

An important contribution to redress the economic and ecologic effects of the drying out of the Aral Sea has been the SYNAS I building of the North Aral Sea dike and the achievement of an operational water level of $42 \mathrm{~m}$. A further step taken by SYNAS II is the raising of the water level to 46 in Saryshignak bay, so that fishery can again reach Aralsk city, albeit with the help of a dredged canal. The measure will be achieved by a dam of $10.3 \mathrm{~km}$ length and an adduction canal of $46 \mathrm{~km}$ length from Syrdarya through Tushibas lake.

The creation of a lake in Saryshiganak bay at a working level of $46 \mathrm{~m}$ to bring back water to the city of Aralsk is an object of highest national priority. Great hopes have been placed on the World Bank financed activities of the SYNAS projects to improve living conditions in the declared zone of environmental and economic disaster. The closing of the Kokaral dike (Phase 1) and the raising of the water level to 42 has shown the effectiveness of this initial measure. The next step (Phase 2) the raising of the water level to $46 \mathrm{~m}$ is universally expected and acclaimed. Great benefits in terms of fishery catch and transport improvement, boatbuilding, fish processing and the subsequent creation of business and job opportunities will provide a great impetus to the economic revival of the region. Other positive effects are related to improvement of environmental conditions and health. The improvement achieved comes at the cost of a high investment in $46 \mathrm{~km}$ of canal in ground material, which may make lining necessary, the dam of $10.3 \mathrm{~km}$ length and additional hydraulic infrastructure. In common economic terms, taking account of only tangible or monetary benefits, the project only provides an unsatisfactory return to capital investment.

Still, taking account of the many intangible and not valued benefits, the realization of project can be recommended without restriction as an important state-borne infrastructural measure. 


\section{References:-}

1. Aladin N, PlotnikovI, Ballatore T, Micklin P (2011) Review of technical interventions to restore the Northern Aral Sea. In: Japan International Cooperation Agency: Study Reports: Country and Regional Study Reports: Central Asia and Caucasus, vol 4, pp 1-12.

2. Akiyanova F. J., Kurochkin, P. J., Faizov K. sh., Churkin A.V., Makulbekov G. B., B. K. Bekniyazov etc. GL.2. Desertification as the degradation of lands /Republic of Kazakhstan.Environment and ecology. - Almaty, 2006. - Vol. 3. - P. 197-254. (in Russian)

3. Balymbetov K. S., Grishaeva O. V. «Forage fishes of the Small Aral sea in 2001-2004»// Fisheries researches in the Republic of Kazakhstan. - Almaty: Bastau, 2005. - S. 406-413.

4. Berezovsky V. G., Auezov E. M., Khrokov V. V. «The current status of the avifauna of the Eastern coast of the Aral sea and perspectives of its changes in connection with the drying of the waters»// the Animal world of Kazakhstan and problems of its protection. Alma-ATA, 1982. S. 30-31.

5. Borovskiy V. M. // "The Drying of the Aral sea and desertification in the Aral sea region of Priaralie" AlmaAta: Nauka, 1981. P. 22-39.

6. Budnikova T. I., Mussatayeva G. B. Ecological problems of the Aral sea region of Kazakhstan. The Russian far East: geography, Hydrometeorology, Geoecology / materials of the seventh scientific conference "For the world days of Water and Meteorology" Vladivostok, 21-22 March 2006 - P. 5-7.

7. Demeeva L. A., Sultanova, B. M., Alimbetova Z. Zh., etc. the Project "Environmental Monitoring of the wetlands of the Delta of the Syrdarya river and the Small Aral". Report for 2013-2015. (in Russian)

8. Dukravets, G. M. the Status and prospects of the lakes of the lower reaches of Syrdarya and their fisheries value in terms of regulating the flow of the river//drying of the Aral sea and desertification in the Aral sea. - AlmaATA: Nauka, 1991. - S. 215-232.

9. Dukhovnyy V (1993) Reclamation and water management of the arid zone.Mekhnat, Tashkent (in Russian)

10. "Innovative Approaches to Ecosystem Restoration: Kazakhstan's Syr Darya Control and Northern Aral Sea Phase I Project”. Water Feature Stories, Issue 28, October 2008.

11. Karajanov K. D., Khaibullin A. S. Soil-ecological monitoring of Kazakhstani Aral sea region// Modern problems of soil pollution. Materials of international scientific conference.Moscow, 2004. P. 214-215.

12. Kornienko V. A., Kiev, R. H., Morizawa N. F., Nekrasova T. F. Scientific bases of the ecological forecast of desertification of hydromorphic landscapes //Problems of desert development. - Ashgabat, 1983, No. 2. - S. 1321.

13. Karajanov K. D., Khaibullin A. S. Alimbaev A. K. "Soil condition of the transition strip from the Delta plains to the dried bottom of the sea./ Problems of Genesis, fertility, irrigation management, soil ecology, assessment of land resources. Almaty. "Tethys", 2002. S. 198-200.

14. Kovalenko A. V. "Ornithological research in the lower valley of Syrdarya river and some adjacent areas in 2005» // KAZ.ornithol. bull., 2005. P. 59-69.

15. Karimov A (1997) Managing water resource scarcity. GFNTI, Tashkent, p 7 (in Russian)

16. Kipshakbayev N., Dukhovny V. A., Ogar N. P. Khaibullin, I. M., Yaprintsev V. V., Tuchman A. N., Achieva K. K. " The restoration of ecological systems of the Syrdarya Delta and Northern part of the Aral sea" . - Almaty, Evero, 2010. - 240 with.

17. Micklin P (2006) The Aral Sea and its future: an assessment in 2006. Eurasian Geogr Econ 47(5):546-567

18. Ogar N. Dinamics of ecosystems and vegetation biodiversity in the Syr-Darya delta // Sustainable use of natural resources of Central Asia.Almaty, 1998. P. 104-107.

19. Popov Y. M. Water-salt regime of soils. Anthropogenic desertification of the Aral sea region soils. - Alma-Ata, 1984. - P. 121-176. (in Russian)

20. Philip Micklin, N.V. Aladin and Igor Plotnikov (eds.) Springer Earth System Sciences “The Aral Sea” 2014.

21. The project «Syrdarya Control and Northern Aral Sea».(SYNAS-1)». 2003-2010

22. The project «Syrdarya Control and Northern Aral Sea».(SYNAS-2)». Feasibility study. A consortium of Companies: Euroconsult - Mott MacDonald ,JacobsBabtie, Danish Hydraulic Institute, Institute kazgiprovodhoz, 2008. 